\title{
XXVI. On the strength of bone
}

\section{B. Bevan Esq.}

To cite this article: B. Bevan Esq. (1826) XXVI. On the strength of bone , Philosophical Magazine Series 1, 68:341, 181-182, DOI: 10.1080/14786442608674108

To link to this article: http://dx.doi.org/10.1080/14786442608674108

曲 Published online: 10 Aug 2009.

Submit your article to this journal $\pi$

Џ Article views: 2

Q View related articles $₫$ 


\section{$\left[\begin{array}{ll}181\end{array}\right]$}

XXVI. On the Strength of Bone. By B. Bevan, Esq.

\section{To the Editor of the Philosophical Magazine and Journal.}

Sir,

IN the lists published by various authors on the cohesive 1 strength of materials, the strength of bone has been much underrated. In the Encyclopadia Britannica it is quoted from Muschenbroek's experiments to be 5,250 pounds per square inch; and I have observed this number copied into various other books. But from experiments I have made with considerable care, I find the strength much to exceed that now stater, if the bone is sound and solid. There will always be some variation in the results of experiments of this nature, depending upon the quality of the substance, and also upon the mode of conducting the experiment. I have tried the bones of horses, oxen, and sheep, and find the strength of cohesion per square inch to vary from 33,000 pounds to 42,500. One specimen of fresh mutton bone supported a load in proportion to 40,000 pounds to the square inch for a considerable time, without any visible injury to the bone,-or nearly eight times the strength given by Muschenbroek. The modulus of elasticity of beef bone $I$ have found 2,320,000 pounds, and specific gravity of $2 \cdot 08$. A substance like bone, so universally abounding, possessing such great strength, and considerable flexibility, ought to be restored to its proper place in the scale of bodies, applicable to so many purposes in the arts.

Emerson has given the ratio of the strength of bone to ash as 22 to $8 \frac{1}{2}$. Now by direct force applied to ash, its cohesion appears to be 16,000 pounds to the square inch, making bone upon the ratio above stated to be more than 41,000 pounds, the correctness of which has been confirmed by my experiments.

I have been trying the cohesive force of various species of wood, and find them generally to exceed the strength given by Mr. Barlow in his treatise on the strength of timber.

My apparatus is partly like that used by Mr. Barlow on the direct colnesion; but the mode of applying the load, instead of adding large weights, is that of gradually advancing a given weight along the arm of a lever, allowing the weight to rest occasionally for several minutes, and sometimes for three or four hours. By this machine I found that a good clear-grained specimen of English oak supported a load in proportion to 19,800 pounds to the square inch, for several hours, having left it at seven in the evening with that load suspended with- 
out any visible alteration at 10 o'clock, but at 6 o'clock the following moming a cylindrical pin had been drawn from the large end of the specimen without separating the fibres. We may therefore safely allow 20,000 pounds for the strength of this oak.

In a similar manner a pin was drawn out of a specimen of Spanish mahogany, with a load in proportion to 22,000 pounds per square inch, and ash with a load of 16,000 per square inch. It will be observed that my results considerably exceed those of Mr. Barlow; the dimensions of my specimens were larger than those of Mr. Barlow, and conducted with great care, and with much greater weights to produce fracture. Mr. Barlow's mode of taking the dimensions of his specimens I consider liable to objection, for the silk thread used to measure the circumference of the cylinders would give the diameter too large by the diameter of the thread; and this quantity would be of considerable moment in affecting the area of the cylinders. I shall probably take an early opportunity of sending you the results of my experiments on the cohesion of various species of wood.

Remaining yours truly,

B. Bevan.

P.S. If you think the following dimensions of a gourd worth notice, it is at your service. Now growing at Goldington in the county of Bedford, in the garden of Mr. Addington, a gourd 5 feet 5 inches in circumference, full 11 inches high, supposed to weigh 70 pounds, not at present done growing,-is 8 feet from the root of the vine.

XXVII. Instructions for collecting Geological Specimens. By William Henry Fitton, M.D. F.R.S. V.P.G.S.*

T so often happens that specimens sent from distant places, by persons unpractised in geology, fail to give the instruction which is intended, from the want of attention to a few necessary precautions, that the following directions may perhaps be useful to some of those, into whose hands these pages are likely to fall. It will be sufficient to premise, that two of the principal objects of geological inquiry, are, to determine, 1st, the nature of the materials of which the earth is composed; and, 2ndly, the relative order in which these materials are disposed with respect to each other.

1. Specimens of rocks ought not, in general, to be taken

* From the Appendix to Captain P. P. King's Narrative of a Survey of the Inter-tropical and Western Coasts of Australia." 